\title{
Cycling of surficial sulphur into the lithospheric mantle: constraints from the Kaapvaal craton root
}

\author{
SARA BURNESS ${ }^{1}$, EMILIE THOMASSOT ${ }^{2}$, KATIE \\ SMART $^{3}$ AND SEBASTIAN TAPPE ${ }^{1}$ \\ ${ }^{1}$ University of Johannesburg \\ ${ }^{2}$ Université de Lorraine, CNRS, CRPG \\ ${ }^{3}$ University of the Witwatersrand \\ Presenting Author: sarab@uj.ac.za
}

Multiple sulphur isotopes $\left({ }^{32} \mathrm{~S},{ }^{33} \mathrm{~S},{ }^{34} \mathrm{~S}\right.$ and $\left.{ }^{36} \mathrm{~S}\right)$ are powerful tracers of Earth's deep sulphur cycle through geologic time. This is due to clear differences between crustal and mantle $\delta^{34} \mathrm{~S}$ values, and the restriction of mass-independent sulphur isotope fraction or 'S-MIF' to Archean surficial reservoirs [1]. Surficial sulphur is transferred into the mantle $\left(\delta^{34} \mathrm{~S}\right.$ of around $-1 \%$ ) mainly at subduction zones in the form of sediments, seawateraltered oceanic crust and serpentinised peridotites, which altogether span a wide range of $\delta^{34} \mathrm{~S}$ values from -72 to $+20 \%$. While some sulphur may be lost during subduction zone processing, up to $85 \%$ of a slab's sulphur budget can be retained and transferred deeper into Earth's mantle. Recycled surfacederived sulphur with $\delta^{34} \mathrm{~S}$ values between -18 and $+20 \%$ has been detected in oceanic volcanism, mantle eclogite xenoliths and sulphide inclusions in diamonds, and the presence of S-MIF in mantle-derived materials places tight constraints on the antiquity of the recycled sulphur.

We present SIMS-determined multiple sulphur isotopic compositions of sulphides hosted in eclogite xenoliths from Proterozoic and Mesozoic kimberlite occurrences on the Kaapvaal craton. The eclogites have elemental and oxygen isotopic compositions in support of seawater-altered oceanic lithosphere protoliths. The eclogite-hosted sulphides have $\delta^{34} \mathrm{~S}$ values from -5.7 to $+29 \%$, with the latter representing the highest ever recorded $\delta^{34} \mathrm{~S}$ value for mantle-derived material. The $\Delta^{33} \mathrm{~S}$ values range from -0.29 to $+0.18 \%$ and do not provide a significant S-MIF record. Most of the sulphide $\delta^{34} \mathrm{~S}$ values range between -6 and $+4 \%$ and have probably retained an isotopic memory from sulphides within altered oceanic lithosphere. In contrast, the highly positive $\delta^{34} \mathrm{~S}$ values from +13 to $+29 \%$ detected in sulphides from a single xenolith are similar to marine sulphates, which were probably a minor component of the oceanic protolith. The lack of a significant S-MIF signature in the eclogitic sulphides implies that the recycled sulphur stems from a surficial reservoir younger than $2.4 \mathrm{Ga}$ in age. Either the eclogites and sulphides formed during post-Archean oceanic crust generation, or the sulphur was introduced into the Kaapvaal craton root during a relatively young metasomatic event.

[1] Farquhar et al. (2002). Science 298, 2369-2372. 